\title{
Nigerian Wood Waste: A Dependable and Renewable Fuel Option for Power Production
}

\author{
Kehinde Oluoti, Godswill Megwai, Anita Pettersson, Tobias Richards \\ Swedish Center for Resource Recovery, University of Boras, Boras, Sweden \\ Email: kehinde.oluoti@hb.se, oluotikehinde@yahoo.com
}

Received 5 June 2014; revised 23 July 2014; accepted 7 August 2014

Copyright (C) 2014 by authors and Scientific Research Publishing Inc.

This work is licensed under the Creative Commons Attribution International License (CC BY). http://creativecommons.org/licenses/by/4.0/

(c) (i) Open Access

\begin{abstract}
Being an oil-rich country, Nigeria's energy supply is primarily fossil-based. The unequal distribution of oil wealth, along with agitation for self-determination and resource control, has led to the sabotage of oil installations. This, in turn, has affected all services running on the energy supply from these installations, leading to incessant or total shut-down of such facilities. Power generated using biomass-based renewable energy technologies is a promising option in limiting the country's dependence on fossil energy for power generation. The most important part of this option is on-site power generation via mini-grid systems. The power thus produced is utilized with the excess being fed into the national grid based on Feed-in-Tariff (F.i.T.) requirements and technicalities. The important factors to be considered in the propagation of a mini-grid option are examined in this study. Furthermore, the study shows that about 1.3 TWh of electricity can be generated from the 1.8 million tonnes per year of wood waste produced by the lumber industry in Nigeria. Power generation through the utilization of biomass has however proved to be a possible path in achieving economic, social and environmental sustainability in the country. Economic studies show that for small-scale power generation, internal combustion engines and Stirling engines are economically feasible. Steam turbines and gas turbines are mostly used in medium/large-scale biomass power generators, especially in proximity to biomass waste resources. Micro gas turbine power technology can also be applied on a small scale despite its high total investment capital.
\end{abstract}

\section{Keywords}

Nigeria, Wood Waste, Renewable Energy, Mini-Grid, Power Technologies

\section{Introduction}

Nigeria is a federal constitutional republic. It has 36 states and a federal capital territory called Abuja. The

How to cite this paper: Oluoti, K., Megwai, G., Pettersson, A. and Richards, T. (2014) Nigerian Wood Waste: A Dependable and Renewable Fuel Option for Power Production. World Journal of Engineering and Technology, 2, 234-248. 
country became independent in 1960 having being colonized by the British in the late nineteenth and early twentieth century. It is located in western Africa on the Gulf of Guinea, with a total area of $923,768 \mathrm{~km}^{2}$, and shares borders in the west with the Republic of Benin, with Cameroon and Chad in the east and Niger in the north [1]. The population of Nigeria was estimated at 138 million in mid 2008, and the annual population growth rate was about 2.38 percent [2]. The landscape in Nigeria is varied. Having a tropical rainforest climate, the annual rainfall in the far south is between 1500 and $2000 \mathrm{~mm}$. The agro-ecological zones of the country are broadly divided from south-north in the sequence mangrove, fresh water swamp, rain forest, tall grass savanna, short grass savanna, and marginal savanna [3]. The climate is varied: from humid and sub-humid in the south, to semi-arid in the north. The considerably high annual volume of rainfall allows the government-controlled forest reserves to thrive extensively throughout the country. Nigeria as a whole has a total of about 11.1 million hectares of forest and 5.5 million hectares of other wooded land [4] and wood waste from these huge landmasses could be explored as fuel for power generation purposes.

The major wood processing industries in Nigeria are typically large capacity facilities, such as sawmills, plywood mills, pulp and paper plants. There are also quite large numbers of small-scale wood companies manufacturing wooden products such as furniture, and many cabinet makers and carpenters. Round-wood in Nigeria comes mostly from the natural high forest zone of the country, in particular from the Southern State of Cross River, Edo, Delta, Ogun, Ondo, Ekiti, Osun and Oyo States [5].

\section{The Use of Nigerian Crude Oil to Produce Power and Its Issues}

Nigeria is the world's sixth largest producer of oil [6]. Crude oil forms the backbone of its economy, accounting for about $90 \%$ of the country's total exports. The low sulphur content of Nigerian oil makes it attractive to many countries that purchase oil on the international market. Agriculture was the main source of income of the people prior to the discovery of oil in 1957, when the first well was located at Oloibiri in Bayelsa State. It is on record that, from this particular well and some other ones, Nigeria made quite a fortune from oil exportation, earning billions of dollars in oil revenues since the early 1970s [6]. The Niger Delta region is home to most of the Nigerian oil wells, but the area has failed so far to enjoy the benefits of such huge revenue accruing in the coffers of the government. This is evident from the neglect of the region by the federal government: most basic amenities are nowhere to be found when compared with other parts of the country. This abandonment has led to the people asking for a greater share of the income generated by the oil resources. Agitation ultimately led to oil pipelines being vandalised, asa well as sabotage and oil experts being abducted. Several armed militant groups, such as the Nigeria Delta Peoples Volunteer Force (NDPVF), the Niger Delta Vigilante (NDV) and, the most noted, Movement for the Emancipation of the Niger Delta (MEND), came on board and took up arms against the Nigerian state. As a result of this development, revenue derived from the sale of crude oil decreased. According to Paki and Ebienfa [7], the nation's major source of revenue (oil) is affected adversely by the activities of militants, and has a serious effect on the ability of the state to export oil from its installations and facilities.

Several services dependent on products of refined crude oil for their activities were negatively affected. Many power generation stations scattered over the states of the federation lost their supply of natural gas so that their power output either decreased dramatically or ceased altogether. Such a power shortfall affects both individuals and companies, forcing them to resort to use generators and other means of producing power in order to continue with their activities. Several companies relocated from Nigeria as a result of power shortage and the high cost of fuelling generators keeps increasing. Considering the non-renewable nature of fossil energy, coupled with never ending agitation for resource control in the Niger Delta regions, the solution to power problems in Nigeria may be the employment of a new renewable option.

\section{The Power Situation in Nigeria}

The Power Holding Company of Nigeria (PHCN), formerly the National Electric Power Authority (NEPA) was an organization that ran the affairs of the electricity sector in Nigeria. The installed total capacity of the Nigerian electricity grid is 8039 MW as supplied by 14 generation stations, 11 of which are thermal and 3 hydro (Table 1). The transmission network is composed of about $5000 \mathrm{~km}$ of $330 \mathrm{kV}$ lines, about $600 \mathrm{~km}$ of $132 \mathrm{kV}$ lines and $330 / 132-k V$ substations (23 in total) with a total combined capacity of 6000 MVA at a utilization factor of $80 \%$. The capacity of the hydro turbines is $34.89 \%$, gas turbines $35.27 \%$ and steam turbines $29.84 \%$. The total relative contribution of hydropower stations to the overall generation of power is greater than that from the thermal power 
Table 1. Power plants in Nigeria using renewable fuel as generation source.

\begin{tabular}{cccccc}
\hline Power Station & Generating Source & Type & Capacity & Status & Year of Completion \\
\hline Kainji Power Station & Hydroelectric & Reservoir & $800 \mathrm{MW}$ & Operational & 1968 \\
Jebba Power Station & Hydroelectric & Reservoir & $540 \mathrm{MW}$ & Operational & 1985 \\
Shiroro Power Station & Hydroelectric & Reservoir & $600 \mathrm{MW}$ & Operational & 1990 \\
Kano Power Station & Hydroelectric & Reservoir & $100 \mathrm{MW}$ & Under Construction & 2015 \\
Zamfara Power Station & Hydroelectric & Reservoir & $35 \mathrm{MW}$ & Under Construction & 2015 \\
Kiri Power Station & Hydroelectric & Reservoir & $100 \mathrm{MW}$ & Under Construction & 2016 \\
Mambilla Power Station & Hydroelectric & Reservoir & $3050 \mathrm{MW}$ & Under Construction & 2018 \\
\hline
\end{tabular}

Source: [8].

stations. Despite the evident importance of the electricity subsector in the socio-economic development of the population, only about $50 \%$ of the total population has access to electricity in Nigeria. The power sector has been in crisis for many years. Although the list of power generating plants in Nigeria keeps growing, much of the generation, transmission and distribution mechanisms have become out of date or are non-functional, while gas inputs to the nation's power generating facilities that rely on gas from the Niger Delta area are being constantly vandalized by militants. Compared with Brazil and South Africa, Nigeria's electricity consumption per capita is approximately $7 \%$ and 3\% respectively with about half of Nigerian households not being connected to the national grid [9]. Self-generation (diesel or petrol generators) in Nigeria is estimated at $6000 \mathrm{MW}$, and it is estimated that about N80 (€0.36)/kWh is spent burning kerosene and candles [9]. Power generated using diesel costs manufacturers in excess of N60 (€0.27)/kWh, while willing individuals pay about N50-70 (€0.22 - 0.31)/kWh for selfgeneration. This can be compared to grid power which, if available, costs between N18 and 23/kWh (€0.08 - 0.10). Economic growth in Nigeria is being seriously affected by the lack of a stable source of power. Should the current power situation continue until 2020, the Nigerian government estimates that a total of USD130bn (€94.5bn) in GDP will be lost annually [9].

Issues in the power sector, principally concerning power outages and unreliable service, compelled the Nigerian government to take radical action. It called for the dismantling of the national power utility company into a series of 18 successor companies: six generation companies, 11 distribution companies covering all 36 Nigerian states and, finally, a national power transmission company. The act stipulated that ownership of these companies should be granted by the Bureau of Public Enterprises (the privatization arm of the federal government) and the Ministry of Finance Incorporated. This reconstruction paved the way for an ambitious privatization programme to be carried out by the Bureau of Public Enterprises in Nigeria. With the liberalization of the power sector providing authorization for private investors to construct and operate power generation facilities, the construction, ownership and/or operation of generation facilities now requires a license from National Electricity Regulatory Commission (NERC), issued pursuant to the EPSR Act. The only exemption to this is the case of captive generation, which the Acts defines as the production of power not exceeding $1 \mathrm{MW}$ with a distributive capacity not exceeding $100 \mathrm{~kW}$, for the exclusive use of the generator [10].

However, the Federal Government of Nigeria and the private sector are set to explore the possibilities of generating power from renewable sources (with the exception of water), which may include the sun, wind, biomass, geothermal sources and ocean tides [11]. According to [12], there is a set notable barriers to the free access of renewable energy in Nigeria that includes include finance and investment, policy and regulations, technology, quality control and standards, public awareness and an insufficient supply of resources. Stakeholders and policy workers should attempt to address these shortcomings and others to enhance the sustainability of renewable energy propagation in Nigeria [13].

\section{Wood Waste to the Rescue}

Biomass resources such as municipal solid waste and animal waste, agricultural crops and residues, as well as forestry resources, are common in Nigeria. Given that they are available extensively, especially wood waste, there is a large potential for their use in producing biofuel [14]. 
The use of biomass can, however, control the instability in the power sector. Table 2 provides an estimate of the amount of wood waste produced (tonne per day) in some cities situated in the southwest region of the country.

Sawmills, by their very nature, generate much waste: sawdust, wood off-cuts, wood backs, plain shavings, wood rejects, etc. In the absence of proper disposal methods, these wastes are burnt in the open air, dumped along the bank of streams and rivers or left on any available space to rot (Figure 1 and Figure 2) [15]. Sambo [16] estimates that the amount of sawdust generated in Nigeria is about 1.8 million tonnes per annum, While Francescato et al. [17] reports that the corresponding figure for wood waste is 5.2 million. As the demand for wood and its products increases, the volume of wastes being generated obviously increases too. Hence, one of the environmental problems facing cities and towns today is the proper disposal of the wastes being generated daily by
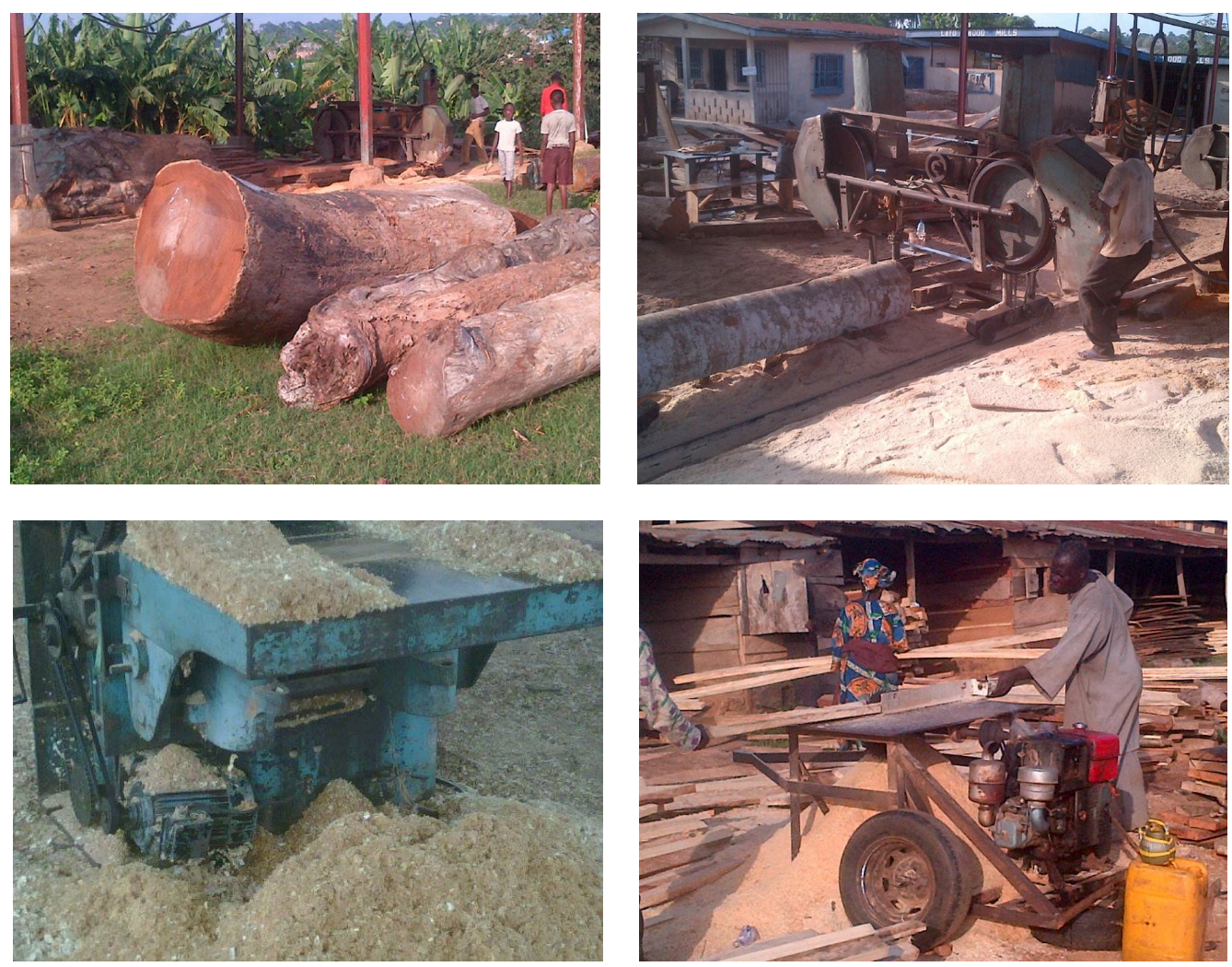

Figure 1. Typical activities such as debarking, canting, trimming and wood planing that generate wood waste in a Nigerian sawmill. Photos: Babafemi Oyebamiji.

Table 2. Mass flow of wood waste generated in southwest Nigeria.

\begin{tabular}{cc}
\hline City & Wood Residues (tonne/day) \\
\hline Lagos & 810 \\
Abeokuta & 1340 \\
Ibadan & 70 \\
Ilorin & 70 \\
Ado-Ekiti & 20 \\
Akure & 10 \\
Ile-Ife & 20 \\
Total & 2300 \\
\hline
\end{tabular}

Source: [15]. 

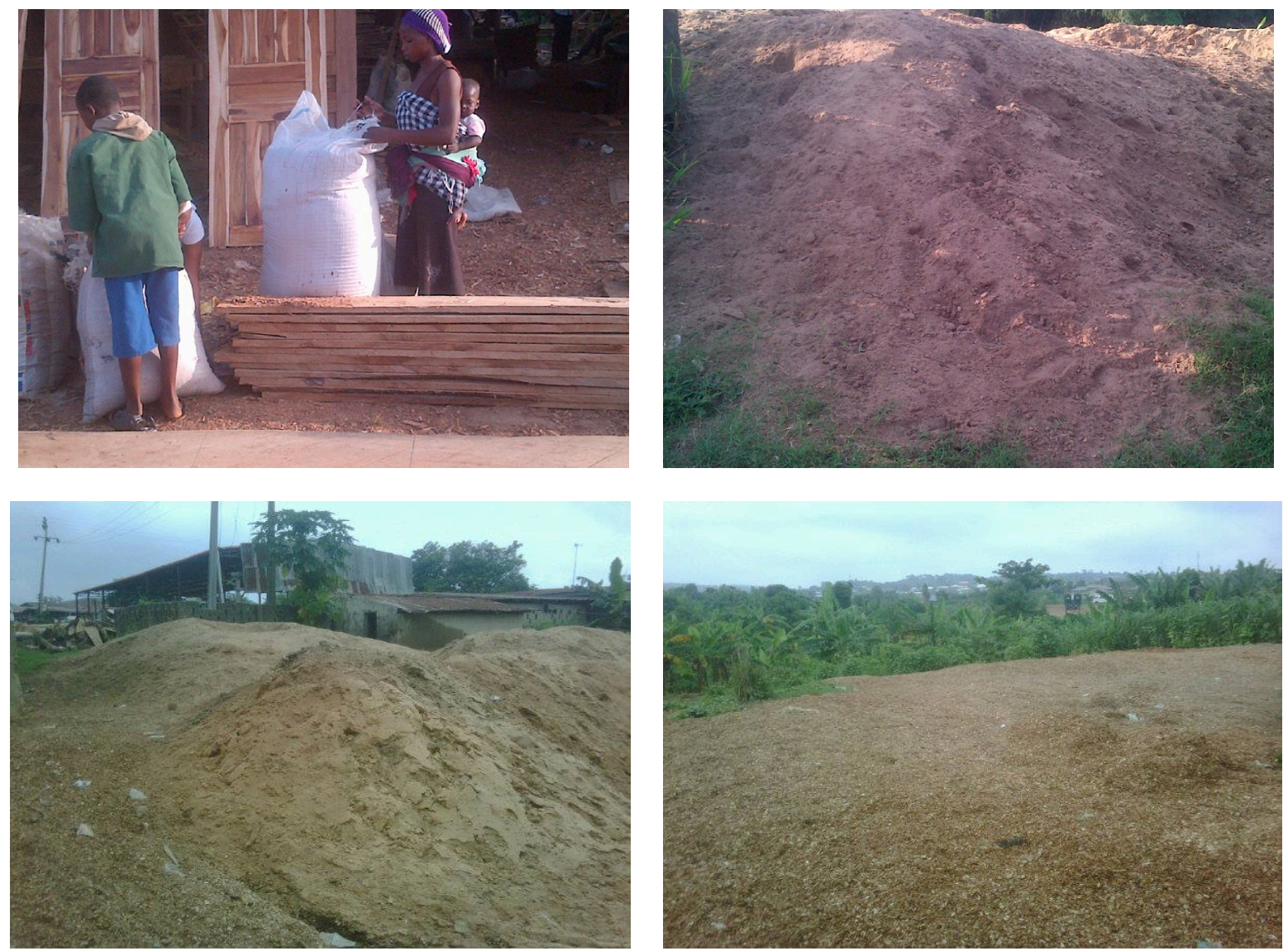

Figure 2. Domestic collection and dumping of wood waste in and around a Nigerian sawmill. Photos: Babafemi Oyebamiji.

the ever-increasing activities of the sawmills [18]. Odewunmi [19] observed that waste generation is connected with everyday living: it cannot be avoided. With numerous attendant problems being caused by the lack of correct management of theses wastes, it is imperative that every effort be made not only to undertake proper management but also to put it into good use, as is the case in developed countries. On the part of the government, a workable policy should be formulated, implemented andfollowed to a logical conclusion.

In the event of a system failure or a complete absence of genuine and efficient waste management, varieties of unpleasant situations become prevalent, and may include flooding as a result of drains and waterways being blocked during the raining season. They can also constitute impediments for wood workers due to unprecedented accumulation of wastes over a period of time, affecting work rate negatively and ultimately, leading to a reduced output. According to Bello and Mijinyawa [20], wood disposal methods employed on mill sites include:

- Agricultural uses, including material for animal bedding.

- Burning on dump sites and open spaces on a daily basis.

- Fuel for use by food vendors and other individuals for cooking and other purposes.

Meanwhile, the huge volume of wood waste generated (by sawmills and other wood industries) in and around Nigerian cities and towns poses environmental and health challenges. Wood waste can however be utilized directly as fuel by public and private power facilities in dedicated power systems. Utilizing biomass waste as an energy source (fuel) converts environmentally detrimental materials (such as residues from agricultural lands, forests and wood processing industries) into fuel materials. Considering emerging global trends, the current desire for mitigating climatic changes, and the push to empower consumers in both developing and developed worlds magnify the need for a less-centralized generation, transmission and distribution of energy [21]. If developed well, studies and projections have shown that several Renewable Energy Technologies (RET) would be in a position to compete with fossil fuels by 2025. Moreover, a better and well-managed energy investment and local production of RET in developing countries, coupled with an enhanced focus on R \& D for RET and energy efficiency are 
highly essential if this goal is to be achieved [22]. In general terms, renewable energy resources, if fully harnessed, could serve as a means of reducing poverty significantly, as well as enhancing sustainable development, in Nigeria [23].

\section{Environmental Impacts of Poor Wood Waste Management}

\subsection{Present Circumstances}

Prominent environmental problems caused by the poor management of wood waste include emission into the air of toxic and non-toxic particulates, emissions from veneer dryer machines affects the workers and others living in the vicinity and is a serious health hazard. Wihersaari [24], who studied methane and nitrous oxide emissions from wood chips, estimated that about $136 \mathrm{~kg}$ of carbon dioxide equivalents $\left(\mathrm{eCO}_{2}\right)$ are emitted per tonnes of chips that are dried naturally in piles for a period of 6 months.

Inland waters in Nigeria are polluted by organic discharges that pose serious threats to the environment, according to Francis et al. [25]. A very common threat is the discharge of biodegradable wood waste from sawmills and other wood-processing factories sited near streams and canals. Pollutants, such as inert solids, originate from wood shavings and leachates; when released into an aquatic environment, they cause a reduction in light penetration which in turn, limits the productivity of, and causes impairment to, the organisms living in that particular ecosystem.

\subsection{Mitigation Plans and Projected Outcomes}

Wood waste from sawmills may be used in a variety of ways, including the production of particleboard [26], mushroom and charcoal [27], chemicals and enzymes [28] and briquettes [29]. Alternatively, together with bark, it can be used as fuel for producing energy [30].

Jeffrey [31] reports that the combustion options of using wood waste as fuel has a carbon offset comparable with the use of natural gas or coal. Its great advantage is that it does not emit greenhouse gases (GHG) which is the direct contrast to the extraction, refining, distribution and combustion of natural gas and coal when they are used as fuels.

\section{Promoting the Generation of RE-Based Electricity: Policies and Regulatory Frameworks}

The Nigerian Government have, over the years, rolled out several policies and regulatory frameworks to promote rural electrification and power generation using renewable sources of energy. These are as outlined below:

\subsection{The National Energy Policy (NEP), 2003}

All energy sectors are covered by this policy. The main targets for the power sector are (a) to ensure that $75 \%$ of the population has access to electricity by 2020, (b) to provide electricity to cities and local government headquarters by 2010, and (c) to promote the participation of the private sector. The country's renewable energy resources are to be promoted as is a decentralized energy supply (particularly in rural areas) based on RE resources: efficient methods in the use of biomass energy resources enhanced, the trends of international developments in renewable energy technologies and applications copied, and efforts made to change the mindset of people who use wood as fuel for cooking [32].

\subsection{The Electricity Power Sector Reform Act (EPSR), 2005}

The Act reiterates the Federal Government's plan to increase access to electricity in rural areas from $40 \%$ in 2005 to $75 \%$ in 2015. The expansion of the main grid, the development of isolated and mini-grid systems, the creation of an enabling environment to promote investments in RE power generation and the fostering of public and private sector partnerships designed to supply electricity to the rural population are all aims of the rural electrification strategy and plan [33].

\subsection{Nigerian Renewable Electricity Policy (NREP), 2006}

The policy was set to 1) elevate biomass as an alternative energy resource in rural areas in particular; 2) enhance 
efficient use of agricultural residues, animal and human waste as sources of energy; and 3) to decrease health hazards by less biomass and agricultural residues being incinerated in the open. The policy also supports the construction of independent renewable electricity systems in areas not covered by the electricity grid. This, in a way, provides a power service for local economic and other sustainability consumptions [34].

\subsection{Renewable Energy Master Plan (REMP), 2007}

REMP foresees increasing the country's electrification demand to a total of 14,000 MW by 2015 of which RE will constitute about $701 \mathrm{MW}$ (5\%). It is envisaged that, by 2025, the total electricity demand will have increased to about 29,000 MW, with RE constituting up to $10 \%$ of the country's overall energy demand. The plan targets contributions to the electricity supply mix from biomass sources to around 50 MW for the year 2015 and 400 MW for 2025 [34].

The Government's plans and policies are in line with the national priorities of enhancing access to rural energy via upgraded rural electrification in the country. Consequently, the plan is to install two 1 MW to increase the share of renewable energy in its power generation [35]. Others plans include 2 and 5 MW wood waste power plants in Ogun and Ondo States, respectively.

The World Bank, in its estimate of power-generating trends for some African countries in the period 2009-2013, indicated the below (Figure 3).

Only Nigeria showed a decline in power generation during this period; Ghana, Ethiopia, Cote d'Ivoire and Angola experienced a steady increase.

\section{Mini-Grid System}

Mini-power plants typically supply 220 V 50 Hz three-phase AC electricity distributed via a low-tension distribution network to homes for domestic power needs, to business outlets (such as markets places, shops, small-scale industries, etc.) and to communities for street lighting, and pumping water [36]. It is estimated that a well-designed mini-grid system can supply electricity for 8 - $10 \mathrm{~h}$ daily, depending on the installed capacity the plant, through on-site generation. In Nigeria, for example, as highlighted under the captive power generation rule, anyone can distribute up to $100 \mathrm{~kW}$ to several clients, and up to $1 \mathrm{MW}$ to a single consumer. Individual entre-

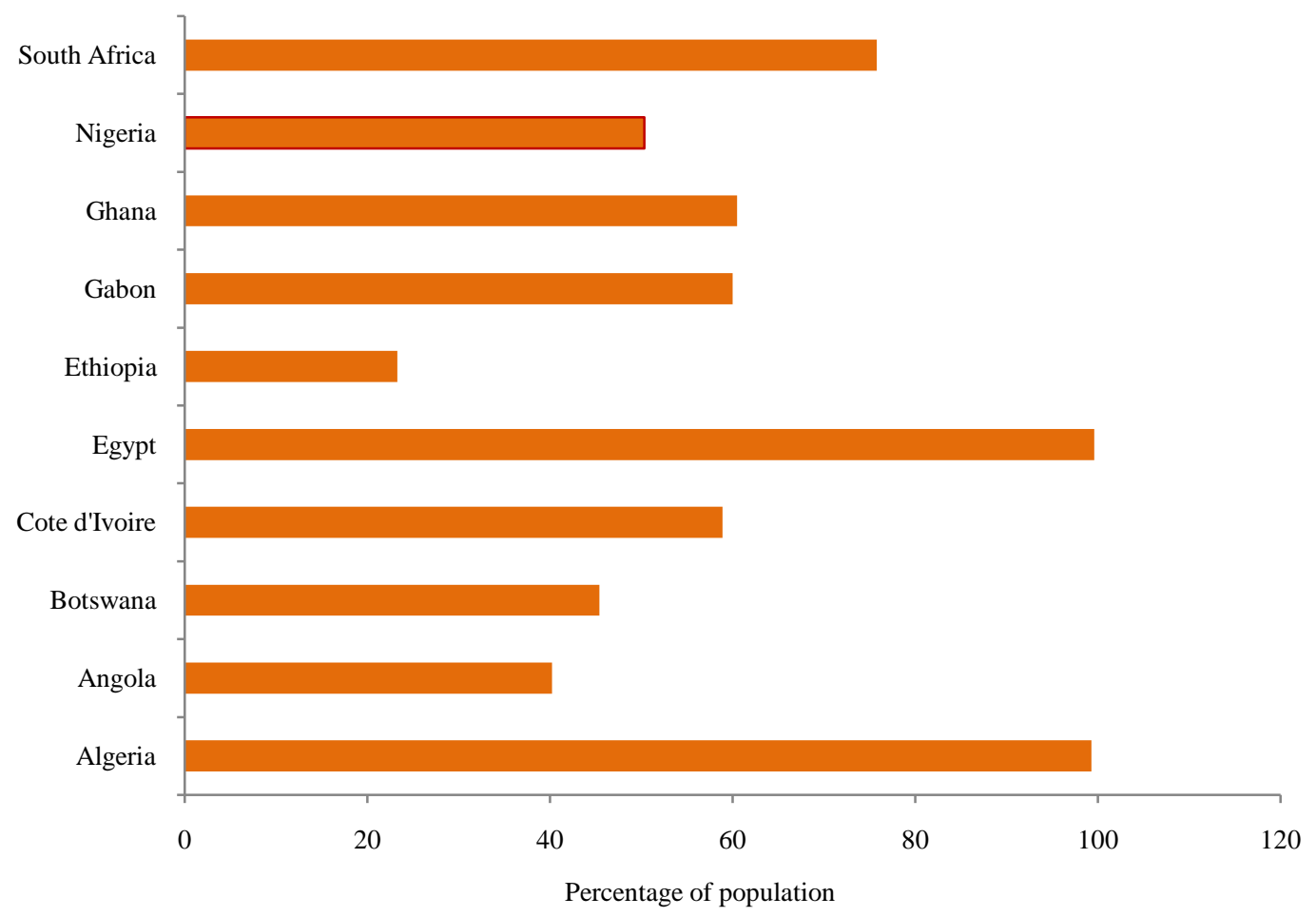

Figure 3. Access to electricity in some African countries in the period 2009-2013 [37]. 
preneurs (or co-operatives) can therefore become small power companies, meeting the needs of a small neighborhood or a cluster of businesses, thereby making money in the process. According to Chaurey et al. [36], a mini-grid system enhances the distribution of generated power to isolated areas not connected to, or far from, the national grid. Modular electricity-generating units in the form of micro turbines based, for example, on renewable resources may have a capacity in tne range of $1 \mathrm{~kW}$ to $50 \mathrm{MW}$. According to Reuters [38], an independent power producer using renewable energy fuel (Revonergy Plc, UK), signed an MOU with the Ondo State Government of Nigeria to build a waste-to-energy (WtE) power plant. The proposed $14 \mathrm{MW}$ power plant will be fuelled by wood waste and sawdust generated by the sawmill industry. The electricity that is produced will be supplied directly to the producer sawmills, with the excess being sold to the national grid based on a long-term agreement to purchase electrical power.

Implementers of electrification in rural areas pay give little consideration to renewable energy alternatives but, with increasing fossil fuel prices the world over, renewable options are becoming all the more attractive [39]. The deployment of renewable sources of energy therefore offers stakeholders the option of supporting power production in a village-scale mini-grid based on the cheap, and environmentally-friendly, generation of electricity.

\subsection{Mini-Grid Systems and Sustainability Issues}

The major barriers facing the development of power generation using biomass as fuel for mini-grids are (1) insufficient investment in RE by the finance/private sector, (2) a lack of awareness and data, (3) a lack of human and institutional capacity, and (4) policy and regulatory shortcomings, such as F.i.T. Financial and operational issues play a critical role in ensuring the long-term sustainability of mini-grids of which a ready and uninterrupted supply of biomass wood waste for use in gasifiers is among the most important. Sustainable technical and financial solutions to address issues that have been identified regarding system operations are instrumental in ensuring the overall success of the system. Post start-up participation by private sector in the running and maintenance of the system is highly desirable as this would ensure system indigenization and closer monitoring. Electrification programmes from mini-grid systems could be enhanced via functioning networks of the participating owner companies, bodies and individuals [40]. In general, targeted capacity building actions, coupled with viable distribution and marketing instruments, are means of ensuring the overall success of the mini-grid system. The strategies proposed, if exploited optimally would enhance the creation of a number of opportunities that include not only jobs and investments but also the propagation of mini-grid systems within the sphere of the energy sector [41].

\subsection{Suitable Sites}

According to Shi [42], the transportation cost of the biomass fuel is an important factor that must be considered when siting a power plant whose fuel material need is based on wood waste. Easy accessibility to fuel materials is ensured if the biomass boiler plant that is to produce electricity is located close to the source of the wood waste as well as to other suitable suppliers. In fact, this is a particularly attractive option for businesses that produce a by-product that can be used as a fuel, either alone or in combination with purchased biomass fuels. It is thus suggested that wood-to-energy power plants be located close to sawmills and other similar wood working industries that produce these waste material. Efforts should be made to provide adequate space for the purpose of supply and storage of fuel. It is also suggested that the distance which fuel has to be transferred to ensure smooth operation is minimized.

A detailed technical/economic feasibility study should be conducted on any sites identified, and an appropriate business plan for the further development of these sites formulated. The study should also include detailed work on the historical generation of biomass at these sites to ensure the sustainable operation of the power plants throughout their life time. All-year-round operating patterns of the related industrial activities, including operational variations during the various seasons (rainy, dry, peak, off-peak, etc.), should be studied to obtain an accurate idea of the availability of the biomass in question. Activities related to the planning and preparation of establishing the mini-grid on the sites on the sites identified by the feasibility study, including an assessment of the electricity demand for all the nearby electricity consumers and their current electricity sources, should be carried out in order to assess the prospect of selling the electricity to them [43].

\section{Energy Recovery and Gasifier Option}

Internal combustion engines, which are typical of energy systems employed in the rural areas of developing 
countries (including Nigeria), are widely used in stationary applications, e.g. the operation of water pumps and mills, and for lighting purposes. A technology such as gasification (Figure 4), which involves the conversion of biomass wood fuel into electrical power, could play a prominent role in accomplishing these. According to Anjireddy and Sastry [44], many developing countries are either in the process of evaluating biomass gasification technology or actually just introducing small-scale biomass gasifiers. Besides using wood as fuel for cooking, gasification of these resources offers a better option for producing power, heat and biofuels for a wider variety of applications. With renewed focus on producing energy from biomass wood waste, it is both possible and encouraging to know that wood waste can be converted using the existing infrastructure and equipment associated with fossil fuels such as coal [45]. It is also important that biomass energy takes the largest share of power generated by non-hydroelectric sources, which includes co-generation and co-firing in coal-fired power plants [45]. Gasification is basically a thermo-chemical process that converts biomass materials into gaseous components, with the reaction taking place in a reactor called a gasifier. The process of gasification as presented in Figure 4 involves loading of the already prepared and processed wood waste as fuel reactant into the gasifier. This is followed by reaction with gasifier agent (steam/oxygen) at relatively high pressure usually higher than 30 bars and at a temperature as high as $1500 \mathrm{~K}$ to produce raw synthetic gas $\left(\mathrm{CO}+\mathrm{H}_{2}\right)$, hydrogen and some other minor byproducts. The syngas is cleaned and eventually used to generate electricity.

Different wood fuels give different energy outputs. In the case of waste woods from forestry versus biomass crops, the energy output of the latter is (24\%), while for the former with its lower moisture content is (18\% - 25\%) and is therefore preferred for gasification [46]. The choice of gasifier for use in biomass conversion is highly dependent on its capacity, the physical and chemical characteristics of the biomass fuel in question and the intended application. Although there are several designs and models of gasifiers, the generic configurations are the same, and include an updraft or countercurrent, a downdraft or concurrent gasifier, a cross draft and a fluidized bed. Wood biomass often contains a lot of tars, which form various compounds and mix with the product gas during reactions in the gasifier. The best way of solving these problems for small-scale units is by making use of a downdraft gasifier, which also suffers less from environmental criticisms as the organic components in the condensate is low. The acid and other tarry products from the fuel pass through a glowing bed of charcoal on their way down the downdraft gasifier configuration and are converted into permanent gases: hydrogen, carbon dioxide, carbon monoxide and methane. This leads to an almost complete breakdown of the tar, thus producing a virtually tar-free gas suitable for use in engine application [47].

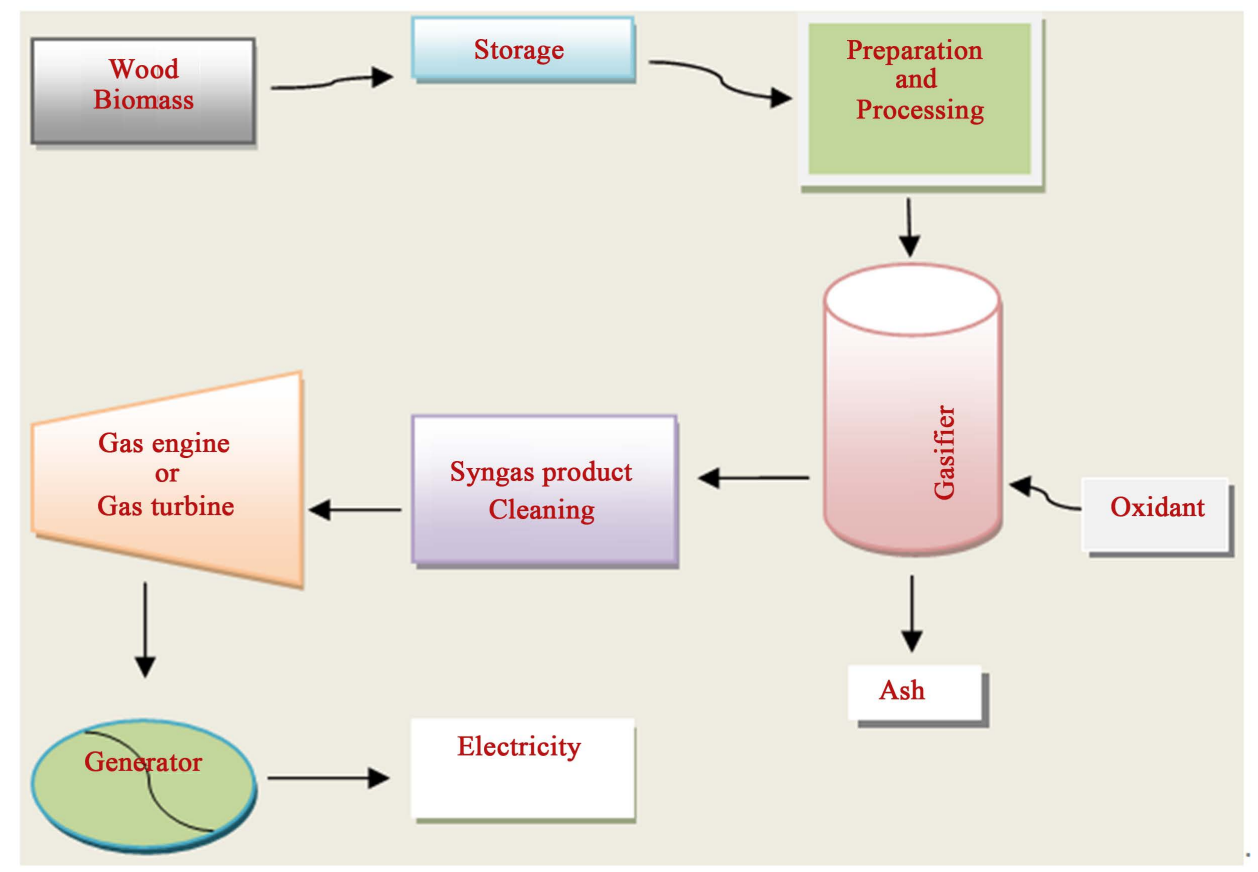

Figure 4. Simplified schematic diagram of the gasification of wood waste biomass in the production of electricity. 


\section{Engineering principle of Downdraft Gasifier (DG)}

The design and construction of a DG makes it highly responsive to the type of fuel used and its qualities. In the case of wood, these include water content (10\% - 25\% mass, dry), grain size $(2-20 \mathrm{~cm})$, share of fine wood particles ( $<15 \%$ mass, wet, $\leq 5 \mathrm{~mm}$ ), and ash content ( $<6 \%$ mass, dry). With water content of the fuel, the mass of steam formed in the dry zone must be removed via the evaporation heat that has to be produced; the vapour must be heated up to the oxidation zone. Heat is removed simultaneously from the oxidation zone through the endothermic: a high temperature must therefore be ensured in the oxidation zone in order to guarantee the effective conversion of the pyrolysis vapour. Consequently, the wood fuel must have low moisture content for effective and adequate conversion of the pyrolysis products [48]. The remaining parameters named above also influence the pattern flow through the fixed bed via slagging, channel formation, increased pressure loss, etc. Both the fuel and the gasification medium are fed through the upper section of the reactor to ensure uniform distribution of the oxidant across the entire cross-section of the reactor. The biomass being converted is subsequently taken through the following steps: drying, pyrolysis, partial oxidation and reduction. The exiting producer gas is loaded with permanent gases $\left(\mathrm{H}_{2}, \mathrm{CO}, \mathrm{CxHy}, \mathrm{CO}_{2}\right.$, and $\left.\mathrm{N}_{2}\right)$ and other products such as particulate matter, dust, soot, tar and ash. The producer gas then undergoes a gas cleaning process to satisfy requirements for eventual use in the gas utilization unit.

\section{Evaluation of Biomass Power Technologies}

The technologies selected for analysis are the following: internal combustion engine power plant, gas turbine power plant, micro-gas turbine power plant, Stirling power plant and steam power plant. The electrical efficiency and economic feasibility of these technologies were investigated for the small-scale production of power using biomass wood waste as the fuel. Furthermore, the total cost of installation and operations, electricity (thermodynamics) and economic analysis are considered as being suitable for carrying out a detailed evaluation and comparison between each technology with regards to estimating electric efficiency. Most of the highlighted technologies are yet to be commercialized; information gathered from operating conditions and parameters obtained from plants make the evaluations possible. Furthermore, for the purpose of comparison, wood waste in the form of sawdust from the Ile-Ife City in Nigeria was used as the feed stream (20 tonne/sec).

\subsection{Evaluation of Electrical Performance}

The electrical efficiency of each power process was evaluated for the reference plants [49] based on the energy value of the biomass fuel and process modification in some of the technologies. Table 3 below presents the electrical efficiency of the wood waste feedstock from Ile-Ife City in Osun State, Nigeria, for different technologies.

The Table 3 shows that internal combustion engine has a better electric output than the other power technologies, although this is based on reference conditions. The micro gas turbine, which operates at a pressure as high as 6 bar, has an electrical performance of 30\% and can be increased to 31\% below an electric output range of $500 \mathrm{~kW}$. This indicates that micro scale production using a micro gas turbine gives a better electric performance [50]. Also, the Stirling engine power system indicates an electric efficiency of $20 \%$ from a nominal electric output range of 10 - $150 \mathrm{~kW}$ irrespective of the fact that yet to be commercialized [51]. It can also be seen from Table 3 that the gas turbine has a lower efficiency compared to the internal combustion engine, but again this result is based on reference conditions [49]. The gas turbine electric performance can increase to about 35\%, which is

Table 3. Evaluation of electrical efficiency.

\begin{tabular}{cc}
\hline Biomass Power Technologies & Electric Efficiency (\%) from Reference Power Plants \\
\hline Micro Gas Turbine & 29 \\
Gas Turbine & 33 \\
Internal Combustion Engine & 20 \\
Stirling Engine & 23 \\
Steam Turbine & 23 \\
\hline
\end{tabular}


higher than that of internal combustion engine. Furthermore, the electricity potential based on Nigerian biomass can be estimated from a waste stream of 56.3 million tonnes produced per annum [16] in the country. Assuming a $35 \%$ electrical performance [49], it may be concluded that about 41 TWh of electricity can be generated from the biomass resources considered, i.e. wood, sawdust, agricultural and municipal solid biomass waste. A breakdown of generating electricity in TWh from different biomass resources in Nigeria is shown in Figure 5.

The estimated potential of generating electricity from these biomass waste resources alone can provide a viable solution to the challenges associated with the inconsistency of power provision in Nigeria, and especially in rural areas of the country.

\subsection{Economic Evaluation}

The following economic performance indicators are considered:

- Fixed capital cost (CFCC): This is associated with building a plant and is comprised of several calculated costs. These include equipment cost (purchase of equipment, material, labour), indirect costs (contractor and engineering expenses, installation and erection of equipment, freight, insurance and construction overheads) and a contingency fund (contingency and contractor fee).

$$
C_{F C C}=C_{B M}+C_{\text {cont }}+C_{\text {fee }}
$$

where $C_{F C C}$ is the fixed capital cost (total module cost), $C^{\circ}{ }_{B M}$ is the bare module cost (equipment cost), $C_{\text {cont }}$ is the contingency fund and $C_{\text {fee }}$ the remaining fees.

- Working capital cost (CWCC): This refers to the capital needed to start-up or run a plant and finance the first period of operation before the process generates revenue. It is simply for the operation and maintenance of the plant, raw material inventories, salaries and any contingencies that arise. It is estimated at $15 \%-20 \%$ of the fixed capital investment, i.e.

$$
C_{W C C}=20 \% \text { of } C_{F C C}
$$

where $C_{W C C}$ is the working capital cost and $C_{F C C}$ is the fixed capital cost

- Total capital investment: The sum of the fixed capital cost and the working capital cost.

$$
C_{T C I}=C_{F C C}+C_{W C C}
$$

Also, the effect of time on the cost of purchased equipment is given by:

$$
C_{2}=C_{1}\left(I_{2} / I_{1}\right)
$$

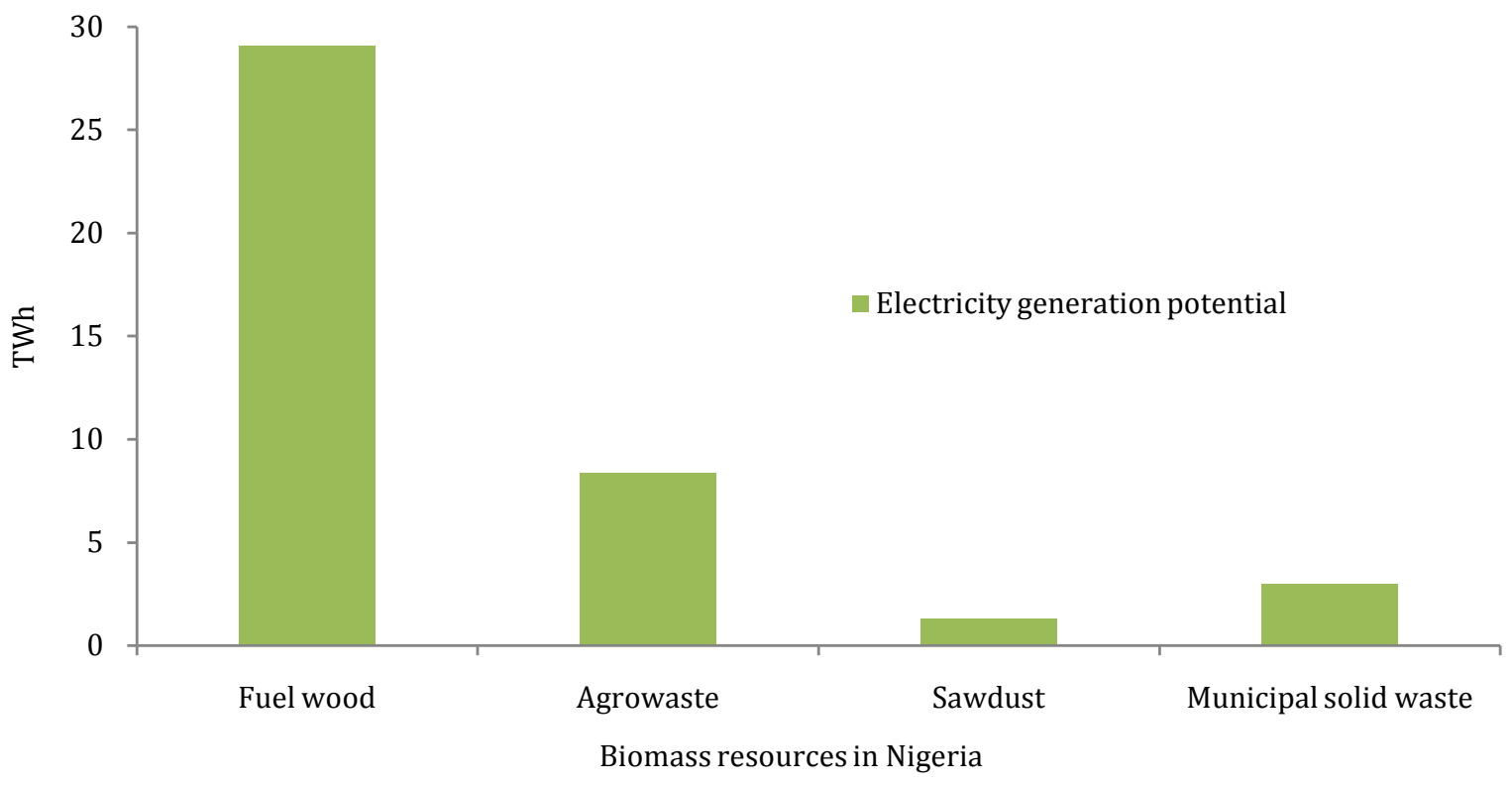

Figure 5. The potential of generating electricity from different biomass waste sources in Nigeria. 
where $C$ is the purchase cost, $I$ is the cost index, 1 and 2 represent the base time when the cost is known, and the time when cost is desired. The effect of capacity on the cost of the purchased equipment is used for evaluating the economic cost of the Stirling engine. This is given by:

$$
C_{a} / C_{b}=\left(A_{a} / A_{b}\right)^{n}
$$

where $C$ is the purchase cost, $A$ is the cost attribute of the equipment, $n$ is the cost exponent (here 0.6 was used) and $a, b$ are the equipment with the required attribute and the base attribute [52]. The gasification of the biomass is added to the list of performance indicators evaluated, as some of the technologies under evaluation require product gas as fuel.

The fixed capital cost (also called the total capital cost) presented in Table 4 includes the purchase of equipment, installation, labour, contingency funds, and all other costs associated with building the power plant. The estimate shows that both the internal combustion engine and Stirling power plants have a low fixed capital cost when compared to other power technologies. Also, the fixed capital costs of gas turbine plants and steam turbine plants indicate that they are mostly designed for centralized or large scale power generation. Furthermore, the cost per unit of small power plants is more than that of large ones [53]. This is known as "economy of scale".

Another parameter considered is the working or running capital cost $\left(C_{W C C}\right)$. This estimated cost takes into account the cost of start-up operation of the power plant and the first few months of operation. The estimated hourly start-up cost $\left(\$ / \mathrm{kWh}_{\mathrm{el}}\right)$ for a micro gas turbine, gas turbine, internal combustion engine, Stirling engine and steam engine is $0.33,0.35,0.16,0.18$ and 0.35 , respectively. The total of $C_{W C C}$ is assumed to be $20 \%$ of the fixed capital cost which covers the operating and maintenance costs, salaries and any other costs pertaining to operations [53]. It is clear from these estimates that gas turbine and steam turbine power technologies require more capital when compared to the others. The micro gas turbine process requires roughly the same capital as the gas turbine for start-up operation whereas the start-up is low for both internal combustion and Stirling engines, which suggests that both technologies can be considered as being economically feasible for producing power on a small scale.

Table 4 also presents the total capital investment cost $\left(\mathrm{C}_{T C I}\right)$ of the different biomass power processes. The internal combustion engine shows a $C_{T C I}$ of $2814 \$ / \mathrm{kW}_{\mathrm{el}}$ with a nominal net electricity output of $578 \mathrm{~kW}$, which is economically feasible when compared to the others. The gas, steam and micro gas turbines indicate $7442 \$ / \mathrm{kW}_{\mathrm{el}}$, $7465 \$ / \mathrm{kW}_{\mathrm{el}}$ and $7306 \$ / \mathrm{kW}_{\mathrm{el}}$ with a nominal net electricity output of $537 \mathrm{~kW}, 415 \mathrm{~kW}$ and $531 \mathrm{~kW}$, respectively. From the economic evaluation, it appears that both the internal combustion and Stirling engines are more economically feasible on a small scale (i.e. decentralized power investment) than gas and steam turbine.

\subsection{Environmental Evaluation: Emissions to Air}

The combination of feedstock and the combustion technology determine the variability in the level of emissions associated with biomass power plants. The common pollutants from such plants are nitrogen oxide, sulfur dioxide, carbon monoxide, and particulate materials (i.e. soot and ash). Gasifier systems equipped with electrostatic precipitators can however, help reduce emissions of $\mathrm{NO}_{\mathrm{x}}, \mathrm{CO}_{2}$ and particulates. The level of $\mathrm{NO}_{\mathrm{x}}$ emissions are affected significantly by the temperature of the flame as well as by the amount of Nitrogen that is present in the fuel being used; other significant factors are the level of excess and the temperature of the combustion air. Particulate materials are controlled effectively through the use of high-grade fuels, and an efficient gasifier set-up that is well adjusted and maintained. A set of notable $\mathrm{NO}_{\mathrm{X}}$ control measures has been the primary focus of research

Table 4. Fixed capital cost $\left(\mathrm{C}_{\mathrm{FCC}}\right)$ and total capital investment $\left(\mathrm{C}_{\mathrm{TCI}}\right)$ for different power plants in Ile-Ife City.

\begin{tabular}{ccc}
\hline Biomass Power Technology & $C_{F C C}\left(\$ / \mathrm{kW}_{\mathrm{el}}\right)$ & $C_{T C I}\left(\$ / \mathrm{kW}_{\mathrm{el}}\right)$ \\
\hline Micro Gas Tubine & 6089 & 7306 \\
Gas Turbine & 6202 & 7442 \\
Internal Combustion Engine & 2814 & 2814 \\
Stirling Engine & 3254 & 3904 \\
Steam Turbine & 6221 & 7465 \\
\hline
\end{tabular}


and development in controlling emissions from biomass power systems, and include the control of emissios from the combustion process, fuel gas recirculation (FGR), low excess air (LEA) firing, burner modification, and water/steam.

\section{Conclusions}

The following conclusions may be drawn from this study:

- Nigeria, among others, would benefit from taking incentives to convert wood waste into power. It would reduce air pollution and, ultimately, help reduce emissions of greenhouse gases. The decision of the Nigerian Government to introduce policies and regulations aimed at enhancing the proper and formal propagation of mini-grids for producing power from wood waste is commendable. The problem of supplying to rural localities that are not connected to the national grid would be solved by the diligent installation of mini-grid systems coupled with proper management, finance and adequate feasibility studies of site suitability and the electricity requirements of the host localities.

- The different biomass power technologies studied (i.e. gas turbine, micro gas turbine, steam turbine, internal combustion engine and Stirling engine) showed that the engines based on generating gas from biomass gave the highest electrical performance, which exceeded $30 \%$. This was possible as a result of the integration of biomass gasification technology for the production of the fuel gas.

- Internal combustion engines and Stirling engines are the most economically attractive for the generation of power on a small scale. The high total capital investment associated with steam and gas turbines explains why they are mostly employed in medium/large scale biomass power plants, especially when they are situated close to the source of biomass. Micro gas turbine power technology can be applied on a small scale even though its total investment capital is high.

\section{References}

[1] Library of Congress-Federal Research Division (2008) Country Profile: Nigeria. http://lcweb2.loc.gov/frd/cs/profiles/Nigeria.pdf

[2] Central Intelligent Agency (2014) Africa: Nigeria. The World Fact Book. https://www.cia.gov/library/publications/the-world-factbook/geos/ni.html

[3] Oguntunde, P.G., Babatunde, J.A. and Lischeid, G. (2011) Rainfall Trends in Nigeria, 1901-2000. Journal of Hydrology, 41, 207-218.

[4] The Food And Agriculture Organization (FAO) of the United Nations (2005) Global Forest Resources Assessment. http://www.fao.org/docrep/008/a0400e/a0400e00.HTM

[5] Bello, S.R. and Mijinyawa, Y. (2010) Assessment of Injuries in Small Scale Sawmill Industry of South Western Nigeria. Agricultural Engineering International: The CIGR Journal of Scientific Research and Development, 7, Manuscript 1558.

[6] Ejibunu, H.T. (2014) Nigeria’s Niger Delta Crisis: Root Causes of Peacelessness. EPU Research Papers, Issue 07/07, 6. http://epu.ac.at/fileadmin/downloads/research/rp_0707.pdf

[7] Paki, F.A.E. and Ebienfa, K.I. (2011) Militant Oil Agitations in Nigeria’s Niger Delta and the Economy. International Journal of Humanities and Social Science, 1, 140-145.

[8] Zarma, I.H. (2006) Hydro Power Resources in Nigeria. Energy Commission of Nigeria. 2nd Hydro Power for Today Conference, Hangzhou, 2006. http://www.unido.org/fileadmin/import/52413_Mr._Ismaila_Haliru_Zarma.pdf

[9] The Light Is Getting Brighter in Nigeria. http://www.theguardian.com/global-development-professionals-network/adam-smith-international-partner-zone/nigeria -power-electricity-africa

[10] Nigerian Electricity Regulatory Commission (2008) (Permits for Captive Power Generation) Regulations. http://www.nercng.org/nercdocs/Regulation-for-Captive-Power-Generation.pdf

[11] Ohimain, E.I. (2012) The Prospects and Challenges of Waste Wood Biomass Conversion to Bioelectricity in Nigeria. Journal of Waste Conversion, Bio-Products and Biotechnology, 1, 3-8.

[12] Oyedepo, S.O. (2012) Energy and Sustainable Development in Nigeria: The Way Forward. Energy, Sustainability and Society, 2, 15. http://www.energsustainsoc.com/content/2/1/15

[13] Sambo, A.S. (2005) Renewable Energy for Rural Development: The Nigerian Perspective. ISESCO Science and Technology Vision, 1, 12-22. 
[14] Agbro, E.B. and Ogie, N.A. (2012) A Comprehensive Review of Biomass Resources and Biofuel Production Potential in Nigeria. Research Journal in Engineering and Applied Sciences, 1, 149-155.

[15] Popoola, L.T., Gutti, B., Adeniran, J.A. and Adeoye, B.K. (2013) The Potentials of Waste-to-Energy System in Nigeria: A Study of Pyrolysis Conversion of Wood Residue to Bio-Oil in Major Cities of South-Western Nigeria. Advances in Applied Science Research, 4, 243-251.

[16] Sambo, A.S. (2009) The Place of Renewable Energy in the Nigerian Energy Sector. World Future Council Workshop on Renewable Energy Policies, 10 October 2009, Addis Ababa, Ethiopia.

[17] Francescato, V., Antonini, E., Bergomi, L.Z., Metschina, C., Schnedl, C., Krajnc, N., Koscik, K., Gradziuk, P., Nocentini, G. and Stranieri, S. (2008) Wood Fuels Handbook. AIEL: Italian Agriforestry Energy Association, Legnaro.

[18] Babayemi, J.O. and Dauda, K.T. (2010) Evaluation of Solid Waste Generation, Categories and Disposal Options in Developing Countries: A Case Study of Nigeria. Journal of Applied Sciences and Environmental Management, 13, 83-88. http://dx.doi.org/10.4314/jasem.v13i3.55370

[19] Odewunmi, S.G. (2001) Solid Waste Transportation in Lagos State: Developing a Sustainable Model. Ph.D. Seminar, University of Lagos, Lagos.

[20] Mijinyawa, Y. and Bello, S.R. (2010) Assessment of Injuries in Small Scale Sawmill Industry of South Western Nigeria. Agricultural Engineering International: The CIGR Journal of Scientific Research and Development, 12, 157-157.

[21] Umar, I.H. (2004) Energy Commission of Nigeria at the Fote One Day Workshop on Nigeria Urban Poor: Energy Needs and Sustainable Livelihoods, 23 June 2004, Lagos.

[22] Olesen, G.B. and Kvetay, M. (2001) Sustainable Energy Vision 2050. INFORSE, No. 12, February 2001.

[23] Nnaji, C.E., Uzoma, C.C. and Chukwu J.O. (2010) The Role of Renewable Energy Resources in Poverty Alleviation and Sustainable Development in Nigeria. Continental Journal of Social Sciences, 3, 31-37.

[24] Wihersaari, M. (2005) Evaluation of Greenhouse Gas Emissions Risk from Storage of Wood Residues. Biomass and Energy, 28, 444-453. http://dx.doi.org/10.1016/j.biombioe.2004.11.011

[25] Francis, O.A., Robert, B.I. and Efe, C.O. (2006) The Impact of Sawmill Wood Wastes on the Water Quality and Fish Communities of Benin River, Niger Delta Area, Nigeria. Wood Journal of Zoology, 1, 94-102.

[26] Particleboard Plant Operates Successfully on 100\% Post Consumer Waste Wood. Green Tech Panels. http://www.woodsymposium.wsu.edu/Proceedings05/Session\%20II\%20pdf\%20files/Kessing.pdf

[27] UNDP (2009) Converting Waste Agricultural Biomass into a Resource. Compendium of Technologies. http://www.unep.org/ietc/Portals/136/Publications/Waste\%20Management/WasteAgriculturalBiomassEST_Compendi um.pdf

[28] Balat, M. and Balat, H. (2009) Recent Trends in Global Production and Utilization of Bio-Ethanol Fuel. Applied Energy, 86, 2273-2282. http://dx.doi.org/10.1016/j.apenergy.2009.03.015

[29] Menind, A. (2012) Peculiarities of Pretreatment and Fuels Refining of Biomass. Ph.D. Thesis, Estonian University of Life Sciences, Tartu.

[30] Oluoti, K.O., Doddapaneni,T.R.K., Kanagasabapathi, D. and Richards, T. (2014) Evaluation of the Pyrolysis and Gasification Kinetics of Tropical Wood Biomass. BioResources, 9, 2179-2190. http://dx.doi.org/10.15376/biores.9.2.2179-2190

[31] Jeffrey, M. (2008) Environmental Impacts from Clean Wood Waste Management Methods: Preliminary Results. Sound Resource Management. http://www.zerowaste.com/docs/Environmental\%20Impacts\%20of\%20Clean\%20Wood\%20Waste\%20Management.pd f.

[32] The Presidency Energy Commission of Nigeria (2003) National Energy Policy. The Presidency and Energy Commission of Nigeria.

http://wacee.net/getattachment/21cca4e4-ef1b-4c59-8501-98b3e8624b88/National_Energy_Policy_Nigeria.pdf.aspx

[33] The Electricity Power Sector Reform Act 2005. Federal Republic of Nigeria Official Gazette. http://www.power.gov.ng/download/Electric\%20Power\%20Sector\%20Reform\%20Act\%202005.pdf

[34] Federal Ministry of Power and Steel (2006) Nigerian Renewable Electricity Policy. http://www.iceednigeria.org/workspace/uploads/dec.-2006.pdf

[35] Ohimain, E.I. (2011) Environmental Impacts of the Proposed 1MWe Wood Gasification Power Plant in Nigeria. Nigerian Journal of Agriculture, Food and Environment, 7, 12-18.

[36] Chaurey, A., Ranganathan, M. and Mohanty, P. (2005) Electricity Access for Geographically Disadvantaged Rural Communities: Technology and Policy Insights. Energy Policy, 32, 1693-1705. http://dx.doi.org/10.1016/S0301-4215(03)00160-5 
[37] The World Bank. Access to Electricity (\% of Population). http://data.worldbank.org/indicator/EG.ELC.ACCS.ZS/countries?display=default

[38] Reuters (2008) Revonergy to Build in Nigeria-14MW Renewable Energy Power Plant Fuelled by Wood. Business Wire. http://www.reuters.com/article/2008/05/21/idUS133006+21-May-2008+BW20080521

[39] Moner-Girona, M. (Ed.) (2008) A New Scheme for the Promotion of Renewable Energies in Developing Countries: The Renewable Energy Regulated Purchase Tariff. JRC Scientific and Technical Reports, p. 5.

[40] Hybrid Mini-Grids for Rural Electrification: Lessons Learned. Alliance for Rural Electrification (ARE). http://www.ruralelec.org/fileadmin/DATA/Documents/06_Publications/Position_papers/ARE_Mini-grids_-_Full_versi on.pdf.

[41] Osueke, C.O. and Ezugwu, C.A.K. (2011) Study of Nigerian Energy Resources and Its consumption. International Journal of Scientific \& Engineering Research, 2, 1-8.

[42] Shi, X., Elmore, A., Li, X., Gorence, N.J., Jin, H., Zhang, X., et al. (2008) Using Spatial Information Technologies to Select Sites for Biomass Power Plants: A Case Study in Guangdong Province, China. Biomass and Bioenergy, 32, 3543. http://dx.doi.org/10.1016/j.biombioe.2007.06.008

[43] Alazraque-Cherni, J. (2008) Renewable Energy for Rural Sustainability in Developing Countries. Bulletin of Science, Technology \& Society, 28, 105-114. http://dx.doi.org/10.1177/0270467607313956

[44] Bhavana, A. and Satry, R.C. (2011) Biomass Gasification Processes in Downdraft Fixed-Bed Reactors: A Review. International Journal of Chemical Engineering and Applications, 2, 425-433.

[45] IEA (2007) Biomass for Power Generation and CHP. Energy Technology Essentials. http://www.iea.org/techno/essentials3.pdf

[46] Waste Wood as a Biomass Fuel: Market Information Report. Waste Infrastructure Delivery Programme. http://www.biomassenergycentre.org.uk/pls/portal/docs/page/resources/ref_lib_res/publications/wastewood-biomass.pd $\mathrm{f}$

[47] (2010) Tar Removal from Low-Temperature Gasifiers. ERA-NET Bioenergy. http://www.ecn.nl/docs/library/report/2010/e10008.pdf

[48] Lettner, F., Timmerer, H. and Haselbacher, P. (2007) Deliverable 8: Biomass Gasification—State of the Art Description. Intelligent Energy, Europe.

http://eaci-projects.eu/iee/fileshow.jsp?att_id=10426\&place=pa\&url=Biomass\%20gasification\%20\%E2\%80\%93\%20S tate\%20of\%20the\%20art\%20description.pdf\&prid=1589

[49] Energi Styrelsen (2012) Technology Data for Energy Plants—Generation of Electricity and District Heating, Energy Storage and Energy Carrier Generation and Conversion. Energinet.dk, Energi Styrelsen, Denmark.

[50] Gimelli, A. and Luongo, A. (2012) 2.3 MW Biomass Steam Power Plant: Experimental and Thermodynamic Analysis. International Conference on Renewable Energies and Power Quality (ICREPQ'12), Santiago de Compostela, 28-30 March 2012. http://www.icrepq.com/icrepq'12/825-gimelli.pdf

[51] Obernberger, I., Carlsen, H. and Biedermann, F. (2003) State of the Art and Future Developments Regarding Small Scale Biomass CHP Systems with a Special Focus on ORC and Stirling Engine Technologies. International Nordic Bioenergy, Jyvaskyla.

[52] Turton, R., Bailie, R.C., Whiting, W.B. and Shaeiwitz, J.A. (2008) Analysis, Synthesis and Design of Chemical Processes. Pearson Education.

[53] Syed, S., Janajreh, I. and Ghenai, C. (2012) Thermodynamics Equilibrium Analysis within the Entrained Flow Gasifier Environment. International Journal of Thermal and Environmental Engineering, 4, 47-54. http://dx.doi.org/10.5383/ijtee.04.01.007 
Scientific Research Publishing (SCIRP) is one of the largest Open Access journal publishers. It is currently publishing more than 200 open access, online, peer-reviewed journals covering a wide range of academic disciplines. SCIRP serves the worldwide academic communities and contributes to the progress and application of science with its publication.

Other selected journals from SCIRP are listed as below. Submit your manuscript to us via either submit@scirp.org or Online Submission Portal.
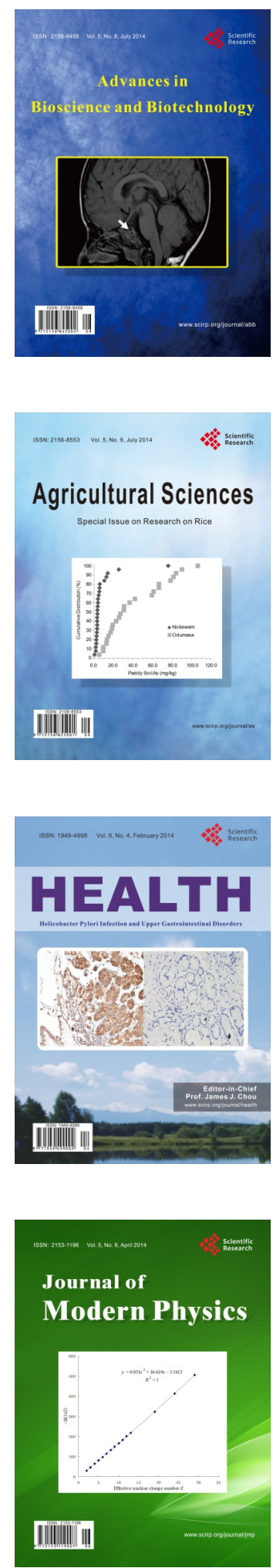
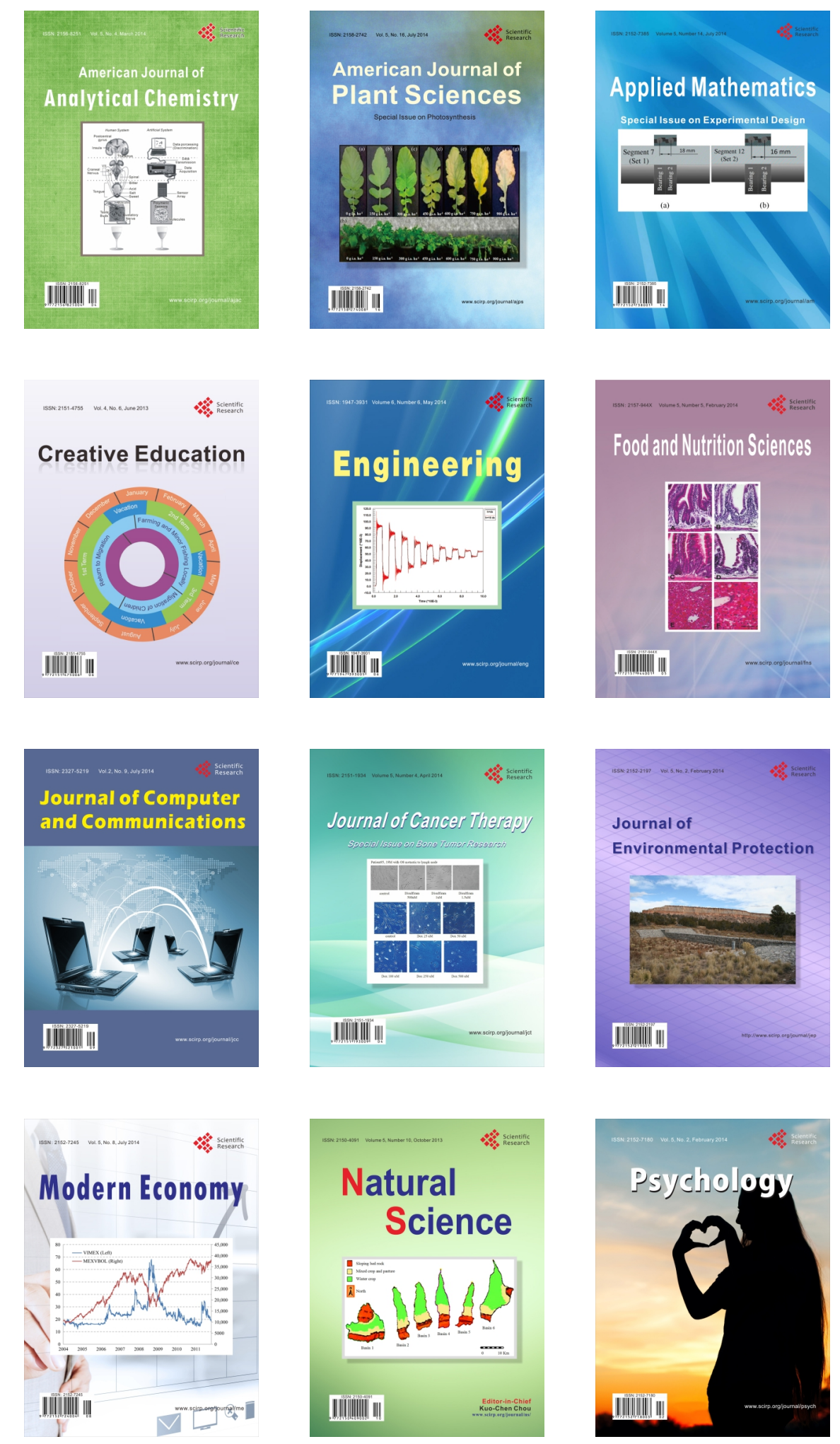